\title{
Physiology of Airway Smooth Muscle Contraction: An Overview
}

\section{Nazinigouba Ouedraogo ${ }^{1}$ and Etienne Roux ${ }^{2,3 *}$}

${ }^{1}$ UFR/SDS University of Ouagadougou, Burkina Faso, France

${ }^{2}$ University of Bordeaux, Adaptation Cardiovascular Ischemia, France

${ }^{3}$ INSERM, Adaptation Cardiovascular Ischemia, France

\begin{abstract}
Bronchial reactivity is a physiological property of healthy airways to develop a moderate airway obstruction in response to various non-specific stimuli, which is altered in several pulmonary diseases. The active effector of airway reactivity is airway smooth muscle (ASM). The contractile status of airway smooth muscle is under the control of many extracellular messengers acting on specific membrane receptors. Binding of the contractile messengers to their specific membrane receptors increases cytosolic $\mathrm{Ca}^{2+}$ concentration $\left(\left[\mathrm{Ca}^{2+}\right] \mathrm{i}\right)$. The shape of the resulting calcium signal is sensed by the contractile apparatus and hence determines the pattern of the contractile response. Agonists can also modify the sensitivity of the contractile apparatus to calcium, via phosphorylation and dephosphorylation of a network of regulatory proteins. These mechanisms can be altered in several respiratory diseases such and COPD, asthma, or exposure to air pollutants, leading to hyperreactivity, which can be pharmacologically controlled by drugs acting on the mechanisms of ASM contraction. The article describes the major intracellular mechanisms responsible for the excitation-contraction coupling in airway smooth muscle cell.
\end{abstract}

Keywords: Lung; Smooth muscle; Calcium; Contraction; Relaxation

\section{Introduction}

Bronchial reactivity is a physiological property of healthy airways to develop a moderate airway obstruction in response to various non specific stimuli. The active effector of airway reactivity is airway smooth muscle, located in the wall of the airways, which contraction induces a reduction in airway lumen and hence an increased resistance to air flow. The contractile state of airway smooth muscle (ASM) is modulated by a variety of extracellular agonists acting on specific receptors located in the plasma membrane of ASM cells (ASMCs). Stimulation of these receptors activates a cascade of intracellular events that lead to ASMC contraction or relaxation. The physiological role of airway reactivity remains unclear. It has been suggested that it may control intrapulmonary air flow distribution and hence ventilationperfusion ratio [1]. Whatever its physiological role, altered airway reactivity plays a key role in various pulmonary diseases. Indeed, various respiratory symptoms are associated with airway obstruction. In asthma, airway narrowing mediated by ASM contraction contributes significantly to obstruction [2-4]. Even if excessive narrowing of airway lumen is asthma can be also due to alteration of non-muscle structures, ASMC contraction, either by excessive stimulation or alteration of its contractile properties, contributes to the pathology and, additionally, drug-induced ASM relaxation contributes to alleviate the consequence of airway narrowing [5]. Bronchial hyperreactivity has been also shown following exposure to air pollutants [6,7], and excessive airway contraction also occurs during bronchospasm, a frightening accident in anesthesia. Its occurrence is higher during induction, and among patients suffering bronchial hyperresponsiveness (BHR). The stimuli generally involved in these accidents are mechanical and allergic, but anesthetic agents can alter the tonicity and the reactivity of airway smooth muscles and hence contribute to the occurrence and the amplitude of bronchospasm [8,9]. ASM physiology is hence a critical determinant of normal ventilatory function and its alterations are deleterious consequences. This review will present an overview of the literature of the main the cellular mechanisms responsible for ASM contractile state and its modulation by extracellular agonists.

\section{General presentation of the physiology of bronchial smooth muscle contraction}

ASM is located in the wall of the tracheobronchial arborescence from the trachea to the terminal bronchioles. In trachea and extralobar bronchi, the smooth muscle strip connects the two extremities of the horseshoe-shape open cartilage ring. In intralobar bronchi, the organization of the cartilage and the smooth muscle is somewhat different, since the smooth muscle forms a continuous layer in the bronchial wall whereas the cartilage does not constitute a continuous structure, and is absent in peripheral bronchi. Contraction of the smooth muscle reduces the airway diameter and subsequently increases the resistance to air flow. The contractile status of ASM is under the control of many extracellular messengers acting on specific membrane receptors. The main ones are neurotransmitters from the autonomous nervous system, epithelial mediators, and mediators released from inflammatory cells. Binding of the contractile messengers to their specific membrane receptors increases cytosolic $\mathrm{Ca}^{2+}$ concentration $\left(\left[\mathrm{Ca}^{2+}\right] \mathrm{i}\right)$, which passes from resting values around $10-7 \mathrm{M}$ up to approximately $10-5 \mathrm{M}$. This $\left[\mathrm{Ca}^{2+}\right] \mathrm{i}$ increase in turn activates the contractile apparatus, which contractile status depends on the $\left[\mathrm{Ca}^{2+}\right] \mathrm{i}$ response pattern. Hence, whatever the intracellular pathways by which each agonist triggers $[\mathrm{Ca} 2+] \mathrm{i}$ increase, time-dependent variations of $\left[\mathrm{Ca}^{2+}\right] \mathrm{i}$, the so-called $\mathrm{Ca}^{2+}$ signal, is the key event that determines ASM contraction [10] (Figure 1).

\section{Nervous and paracrine control of airway smooth muscle contraction}

The parasympathetic nervous system is the major bronchoconstrictor neural pathway in the airways [11], and cholinergic innervation is responsible for airway basal tonus [12]. Cholinergic fibers travel down the vagus nerve into the parasympathetic ganglia

*Corresponding author: Etienne Roux, University of Bordeaux, Adaptation Cardiovascular Ischemia, France, Tel: +33-5-57-89-01-05; E-mail: etienne.roux@u-bordeaux.fr

Received October 28, 2014; Accepted November 24, 2014; Published November 28, 2014

Citation: Ouedraogo N, Roux E (2014) Physiology of Airway Smooth Muscle Contraction: An Overview. J Pulm Respir Med 4: 221. doi:10.4172/2161105X.1000221

Copyright: (c) 2014 Ouedraogo N, et al. This is an open-access article distributed under the terms of the Creative Commons Attribution License, which permits unrestricted use, distribution, and reproduction in any medium, provided the original author and source are credited. 
A
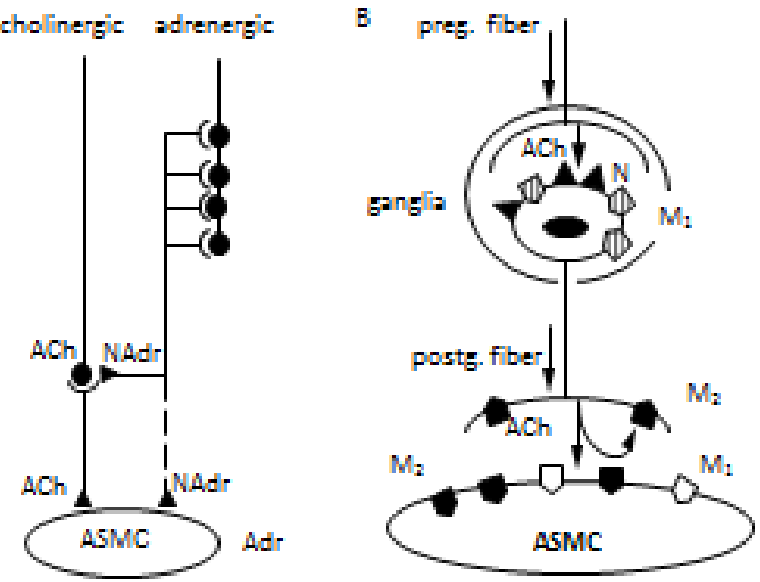

Figure 1: Autonomous control of airway smooth muscle. A. General scheme of the cholinergic and adrenergic innervation controlling airway smooth muscle cell (ASMC) contraction. Black dots represent the nervous ganglia. ACh: acetylcholine. NAdr: noradrenalin. Adr: adrenalin. Cholinergic innervation directly stimulates ASMC contraction. Adrenergic stimulation indirectly modulates ASMC contraction acting of parasympathetic ganglia, with small direct action on ASMC. ASMC may be also sensitive to adrenalin B. Schema of the parasympathetic pathway controlling ASMC contraction. prg. fiber: preganglionic fiber. postg: postganglionic fiber. $\mathrm{N}$ : nicotinic receptor. $M_{1} M_{2}, M_{3}$ : muscarinic receptors type $1,2,3$. Nervous stimulus is transmitted in the ganglia from preganglionic to postgangionic fibers via activation of nicotinic receptors. At the neuromuscular junction, ACh acts on $M_{3}$ and $M_{1}$ receptors on ASMC. $M_{1}$ and $M_{2}$ receptors are responsible for retroactive control of $\mathrm{ACh}$ release in the ganglia, and at the neuromuscular junction, respectively.

within the airway wall. Parasympathetic ganglia density is maximal in proximal airways, around the 5-7th bronchial generations [13]. From these ganglia, short post-synaptic fibers reach the smooth muscle and glands [14,15]. Acetylcholine (ACh), the main neurotransmitter of the parasympathetic nervous system, is released at both ganglionic synapses and postganglionic junctions. In ganglia, ACh acts on postsynaptic nicotinic cholinoceptors responsible for neurotransmission and M1 muscarinic receptors involved in negative feedback. At the neuromuscular junction, ACh activates post-junctional M3 muscarinic receptors responsible for contraction, but also on pre-junctional M2 receptors involved in negative retrocontrol of ACh release [16]. Opposite to cholinergic stimulation, adrenergic stimulation relaxes airways. Though adrenergic innervation of ASM in weak in humans, $\beta 2$-adrenoceptors are largely expressed in ASM $[17,18]$. Additionally, adrenergic fibers may target parasympathetic ganglia, allowing an indirect adrenergic control of airway stimulation [13,19]. In addition with $\mathrm{ACh}$ and noradrenalin, the non-adrenergic non-cholinergic (NANC) component of the autonomous nervous system can release other contracting or relaxant agonists such as neuropeptide $\mathrm{Y}$, substance P, ATP and neurokinines, or vasoactive intestinal peptide (VIP), respectively. However, NANC system is not very developed in human airways and has a small regulatory effect on human airway function $[20,21]$.

In addition with the autonomous nervous system, several cell types located in the airway wall, such as epithelial cells, inflammatory cells, and myocytes themselves, can release a variety of mediators, e. g., histamine, endothelin, ATP, and metabolites of arachidonic acid, that can modulate airway contraction via specific membrane receptors [2226] (Figure 2).

\section{Excitation-contraction coupling in Airway Smooth Muscle Cell}

\section{$\left[\mathrm{Ca}^{2+}\right]$ i signal transduction}

Extracellular $\mathrm{Ca}^{2+}$ influx: $\left[\mathrm{Ca}^{2+}\right] \mathrm{i}$ increase can be due either to extracellular $\mathrm{Ca}^{2+}$ influx through the plasma membrane or to $\mathrm{Ca}^{2+}$ release from the sarcoplasmic reticulum. The canonical way by which agonists can induce extracellular $\mathrm{Ca}^{2+}$ influx is the opening of L-type voltage-operated $\mathrm{Ca}^{2+}$ channels (VOCCs), inhibited by dihydropyridine [27]. Membrane depolarization can occur via several mechanisms. Membrane depolarization is controlled by $\mathrm{K}^{+}$channels, which opening induces an outgoing $\mathrm{K}^{+}$current that tends to maintain a low membrane voltage. At rest, basal membrane potential in ASM cells is around $-60 \mathrm{mV}$, slightly higher than the equilibrium potential for $\mathrm{K}^{+}$[28]. In addition to basal $\mathrm{K}+$ conductance, it has been recently shown that proteins from Transient Receptor Potential (TRP) family, in particular TRPC3, plays a significant role in maintaining the resting membrane potential higher than that of $\mathrm{K}+$ equilibrium potential [29]. $\mathrm{K}^{+}$current is carried out by various $\mathrm{K}^{+}$channels. The main ones are voltage-dependent delayed rectifying $\mathrm{K}+$ channels (KDR), $\mathrm{Ca}^{2+-}$ dependent $\mathrm{K}^{+}$channels, activated by $\left[\mathrm{Ca}^{2+}\right] \mathrm{i}$ increase $(\mathrm{KCa})$, and $\mathrm{K}+$ channels inhibited by intracellular ATP (KATP). Opening of these $\mathrm{K}^{+}$channels tends to limit membrane depolarization, whereas inhibition of these channels increases membrane depolarization. Membrane depolarization is also controlled by $\mathrm{Ca}^{2+}$-activated $\mathrm{Cl}$ - channels and $\mathrm{Ca}^{2+}$, and in some case $\mathrm{Na}+$, entry via several cationic channels [30,31] (Figure 3).

In parallel with voltage-dependent $\mathrm{Ca}^{2+}$ influx, $\mathrm{Ca}^{2+}$ can enter the cell via opening of voltage-independent mechanisms. Receptor-operated channels (ROCs) are ion channels which opening is triggered by the

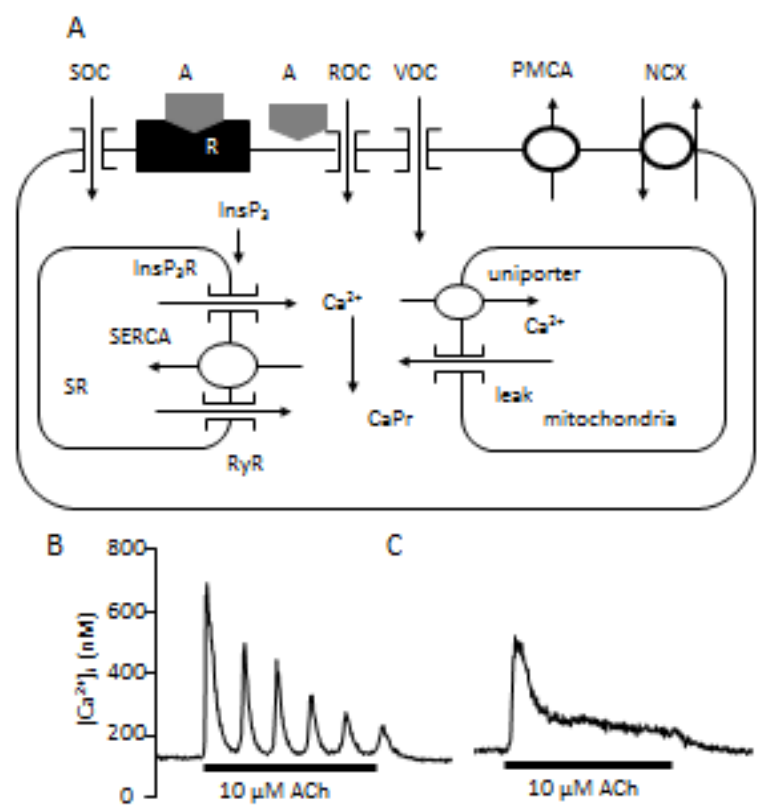

Figure 2: General mechanisms of $\mathrm{Ca}^{2+}$ handling in airway myocyte. SOC: store-operated channel. ROC: receptor-operated channel. VOC: voltageoperated channel. R: G-coupled membrane receptor. A: contracting agonist. PMCA: plasma membrane $\mathrm{Ca}^{2+}$ pump. $\mathrm{NCX}: \mathrm{Na}^{+}-\mathrm{Ca}^{2+}$ exchanger. SR: sarcoplasmic reticulum. RyR: ryanodin receptor. InsP $\mathrm{P}_{3} \mathrm{R}$ : InsP $\mathrm{P}_{3}$ receptors. SERCA: SR $\mathrm{Ca}^{2+}$ pump. CaPr: $\mathrm{Ca}^{2+}$-binding protein. $\mathrm{B}$ and $\mathrm{C}$ : typical oscillating and non-oscillating $\mathrm{Ca}^{2+}$ signal of rat $(B)$ and human $(C)$ isolated ASMC in response to $30 \mathrm{sec}$ ACh stimulation. 


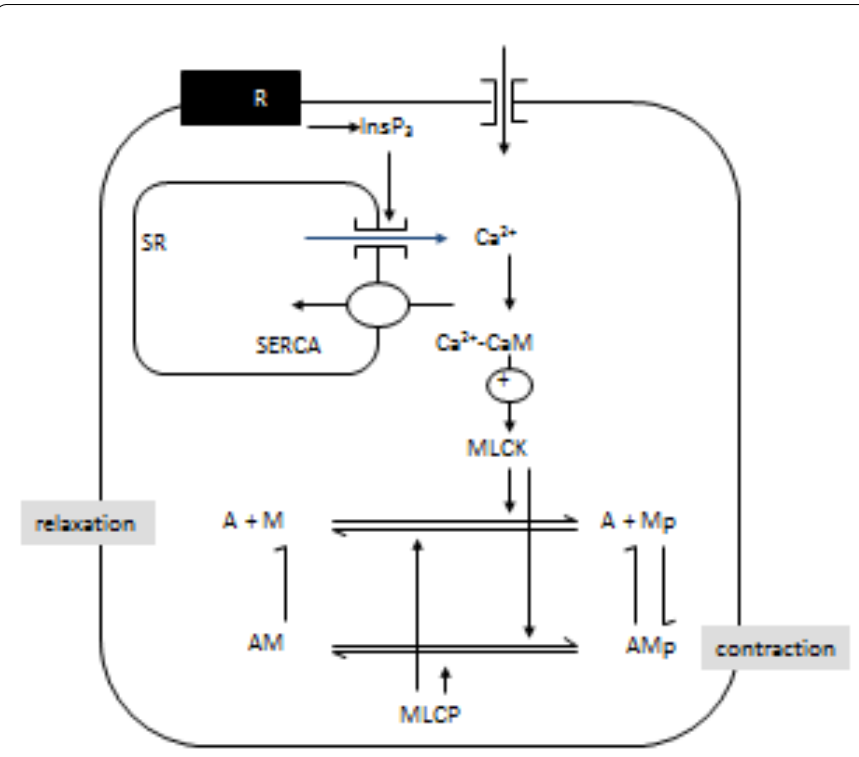

Figure 3: General scheme of excitation-contraction coupling in airway myocyte. $\mathrm{Ca}^{2+}$ increase, either via $\mathrm{InsP}_{3}$-induced $\mathrm{Ca}^{2+}$ release from the sarcoplasmic reticulum (SR) of extracellular influx, binds to calmodulin (CaM). The $\mathrm{Ca}^{2+}$-CaM complex binds to and activates the myosin light chain kinase (MLCK) that phosphorylates the regulatory myosin light chain. Phosphorylated myosin (Mp) can bind to actin (A) to form the phosphorylated actomyosin bridge (AMp). Myosin, either bound (AMp) or unbound to actin $(\mathrm{Mp})$ is dephosphorylated by the myosin light chain phosphatase (MLCP). Actomyosin bridge, either phosphorylated or not, corresponds to contraction, whereas myosin unbound to actin corresponds to relaxation.

fixation of the agonist on its receptor independently from changes in membrane potential. The ion channel can be activated by direct binding of the agonist, the so-called ligand-gated $\mathrm{Ca}^{2+}$ channels, as it is the case for P2X receptor to extracellular ATP [31,32]. Alternatively, some ROCs can be activated indirectly, as it seems the case for histamineinduced contraction in human airways. It has been hypothesized that these ROCs are members of the TRP family $[33,34]$.

Additionally, another way of $\mathrm{Ca} 2+$ input has been described, including in ASM of some species, which is independent from both membrane potential and agonist stimulation. This so-called storeoperated $\mathrm{Ca} 2+$ current (SOCC) is activated by $\mathrm{Ca} 2+$ emptying of the sarcoplasmic reticulum whatever its cause. Two molecular agents of SOCC have been recently identified, Stim and ORAI proteins [29]. Stim proteins are expressed in the sarcoplasmic reticulum (SR) membrane and the plasmalemma, and appear to be the sensor of the level of $\mathrm{Ca} 2+$ storage in the SR, whereas ORAI channels are expressed in the cell membrane and seem to be the $\mathrm{Ca} 2+$ pore sensitive to Stim stimulation $[35,36]$. Occurrence of SOCC has been evidenced in specific pharmacological conditions in ASMCs from various species, including pig [37], guinea-pig [38], rat [39,40] and human [35,36]. The role of SOCC in ASMC has been shown in long-term signals like in ASMC proliferation [39,40], but its contribution to contraction in physiological conditions remains controversial [41].

$\mathrm{Ca} 2+$ release from intracellular store: $\mathrm{Ca} 2+$ release from intracellular $\mathrm{Ca}^{2+}$ store in ASMCs is mainly due to $\mathrm{Ca}^{2+}$ release from the sarcoplasmic reticulum. This is a major physiological mechanism of bronchoconstriction since a variety of agonists, including the major physiological bronchoconstrictor acetylcholine and histamine, act via such a mechanism, the so-called pharmacomechanical coupling. These agonists bind to G protein-coupled 7 transmembrane domain- receptors, such as cholinergic M3 muscarinic receptor (acetylcholine), histaminergic $\mathrm{H} 1$ receptor, purinergic $\mathrm{P} 2 \mathrm{Y}$ receptors [16,22,31]. When stimulated, these receptors activate $\mathrm{Gq} / 11$ protein that in turn activates phospholipase C (PLC). PLC catalyzes the hydrolysis of phosphatidylinositol diphosphate (PIP2) into diacylglycerol (DAG) and inositol 1, 4, 5 trisphosphate (InsP3). InsP3 binds to and opens InsP3 receptors (InsP3R) located in the sarcoplasmic reticulum membrane and hence triggers $\mathrm{Ca}^{2+}$ release from the sarcoplasmic reticulum into the cytosol [42]. Another type of sarcoplasmic $\mathrm{Ca}^{2+}$ channel, the ryanodine-sensitive channel (RyR), is activated by $\left[\mathrm{Ca}^{2+}\right] \mathrm{i}$ and by cyclic ADP-ribose $[43,44]$. Activation of RyR upon contractile stimulation may contribute to amplify an initial $\left[\mathrm{Ca}^{2+}\right] \mathrm{i}$ increase, the so-called $\mathrm{Ca}^{2+-}$ induced $\mathrm{Ca}^{2+}$ release (CICR). Though the contribution of $\mathrm{RyR}$ to the physiological $\mathrm{Ca}^{2+}$ response has been in pig trachea smooth muscle cells $[45,46]$, it has been shown that it does not significantly contributes to the $\mathrm{Ca}^{2+}$ response to cholinergic stimulation in mouse and human and bronchial myocytes $[47,48]$. So, though present in ASMC, the importance of the contribution of RyR in ASM contraction remains controversial [47,49] (Figure 4).

These different stimulation- $\mathrm{Ca}^{2+}$ signal couplings are not independent and may interact in the overall response to agonist stimulation. For example, pharmacological coupling may activate electromechanical coupling via activation of $\mathrm{Ca}^{2+-}$ activated $\mathrm{Cl}$ - channels, which opening tends to depolarize the plasma membrane. Extracellular ATP induces constriction both via pharmacomechanical coupling due to $\mathrm{P} 2 \mathrm{Y}$ receptor activation and through ligand-gated $\mathrm{P} 2 \mathrm{X}$ receptors, which opening allows not only $\mathrm{Ca}^{2+}$ influx that contributes to $\left[\mathrm{Ca}^{2+}\right] \mathrm{i}$ increase but also $\mathrm{Na}^{+}$influx that depolarizes the plasma membrane with subsequent electromechanical coupling activation [31].

Mechanisms of free cytosolic $\mathrm{Ca}^{2+}$ clearance: Basal maintenance of low $\left[\mathrm{Ca}^{2+}\right] \mathrm{i}$ and $\mathrm{Ca}^{2+}$ removal from the cytosol upon and after

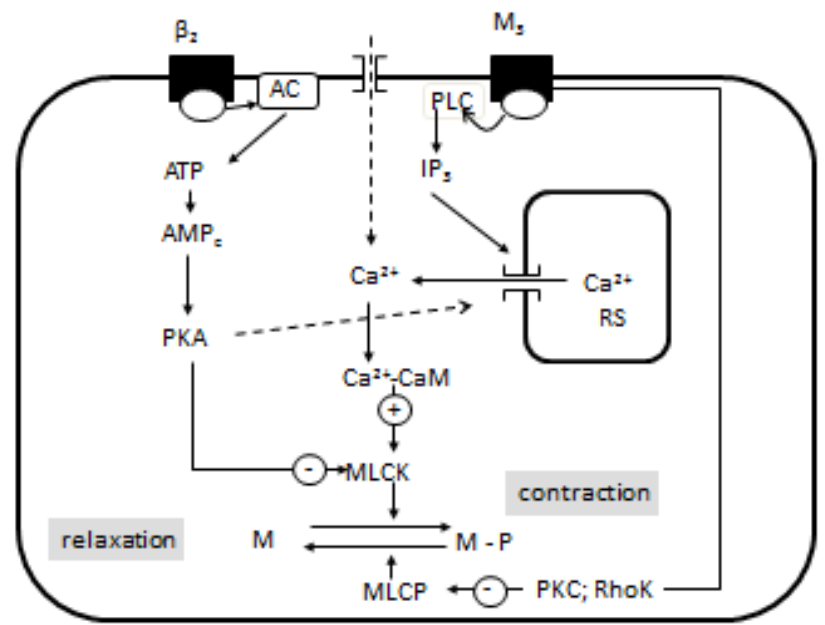

Figure 4: General scheme of intracellular mechanisms of cholinergic and adrenergic stimulation of airway myocyte. Stimulation of muscarinic receptor $3\left(\mathrm{M}_{3}\right)$ activates phospholipase $\mathrm{C}(\mathrm{PLC})$ and $\operatorname{Ins}_{3} \mathrm{P}$ production and $\mathrm{Ca}^{2+}$ release from the sarcoplasmic reticulum (SR), with little extracellular $\mathrm{Ca}^{2+}$ influx. $\mathrm{Ca}^{2+}$ binds to calmodulin (CaM) and activates myosin light chain kinase (MLCK) that phosphorylates the regulatory myosin light chain (M-P) leading to contraction. Additionally, $\mathrm{M}_{3}$ receptor stimulation activates Rho Kinase (RhoK) and protein kinase $\mathrm{C}$ (PKC) that inhibit myosin light chain phosphatate (MLCP), resulting in increased myosin phosphorylation and contraction. Stimulation of $\beta_{2}$ adrenoceptor activates adenylyl cyclase and subsequent cyclic AMP production (cAMP), which activates protein kinase A (PKA). PKA inhibits MLCK and hence contraction and, additionally, may reduce $\mathrm{Ca}^{2+}$ release from the $\mathrm{SR}$. 
stimulation is due to active mechanisms that either extrude $\mathrm{Ca} 2+$ in the extracellular medium or uptake it in intracellular $\mathrm{Ca}^{2+}$ stores. $\mathrm{Ca}^{2+}$ extrusion is mainly due to the activity of the plasma membrane $\mathrm{Ca}^{2+}$ ATPase (PMCA), and the $\mathrm{Na}+-\mathrm{Ca}^{2+}$ exchanger (NCX) [50]. The main mechanisms of $\mathrm{Ca}^{2+}$ uptake from the cytosol are $\mathrm{Ca}^{2+}$ pumping back into the $\mathrm{SR}$ by sarcoendoplasmic $\mathrm{Ca}^{2+}$ ATPase (SERCA) and $\mathrm{Ca}^{2+}$ uptake into the mitochondria [51,52]. Also, several $\mathrm{Ca} 2+$-binding proteins can buffer cytosolic $\mathrm{Ca}^{2+}$ and hence decrease $\left[\mathrm{Ca}^{2+}\right] \mathrm{i}[51,53,54]$.

Shape of the calcium signal: When ASMC is stimulated by contracting agonists, simultaneous activation of the mechanisms of $\left[\mathrm{Ca}^{2+}\right] \mathrm{i}$ increase and $\left[\mathrm{Ca}^{2+}\right] \mathrm{i}$ clearance results in dynamics change in $\left[\mathrm{Ca}^{2+}\right] \mathrm{i}$, the so-called $\mathrm{Ca}^{2+}$ signal. This $\mathrm{Ca}^{2+}$ signal is usually characterized by a transient $\left[\mathrm{Ca}^{2+}\right] \mathrm{i}$ increase, followed either by a progressive decay to a steady-state $\mathrm{Ca}^{2+}$ value above the resting $\left[\mathrm{Ca}^{2+}\right] \mathrm{i}$, the so-called $\mathrm{Ca}^{2+}$ plateau, or by subsequent $\mathrm{Ca}^{2+}$ oscillations. Increase in $\left[\mathrm{Ca}^{2+}\right] \mathrm{i}$ activates the contractile apparatus, and, hence, the contractile behavior of ASM depends on the pattern of the calcium signal $[10,31,37,47,55,56]$. Theoretical modeling has shown that the amplitude of the initial $\mathrm{Ca} 2+$ peak encodes for the velocity of ASMC contraction, whereas the amplitude of the plateau and, when present, the frequency of oscillations, encode for the amplitude of contraction [57,58].

Activation of the contractile apparatus by $\mathrm{Ca}^{2+}$ : The contractile apparatus of smooth muscle is basically composed of thick filaments of myosin and thin filament of actin and associated proteins. These filaments are not organized in sarcomeres and do not form well individualized myofibrils. Thick filaments are anchored on dense bodies in the cell and dense area on the plasma membrane and actin filaments are positioned between thick filaments. Dense bodies and filaments are connected by non-contractile intermediate filaments that constitute an intracellular network. Each monomer of myosin is formed by the association of 2 identical heavy chains (MHC) complexed to 2 pairs of light chains (MLC), a $17 \mathrm{kDa}$ one (MLC17) and a $20 \mathrm{kDa}$ one (MLC20). Whereas the role of MLC17 is unclear, phosphorylation of MLC20 is required for actin-myosin binding, and hence phosphorylation/ dephosphorylation of MLC20 regulates actin-myosin cross bridge and contraction [59]. MLC20 is basically phosphorylated by the myosin light chain kinase (MLCK), whereas MLC20 dephosphorylation is ensured by the myosin light chain phosphatase (MLCP) [60,61]

$\left[\mathrm{Ca}^{2+}\right] \mathrm{i}$ controls the contractile apparatus by the following mechanism: $\mathrm{Ca}^{2+}$ binds to the cytosolic protein calmodulin $(\mathrm{CaM})$ and the $\mathrm{Ca}^{2+}-\mathrm{CaM}$ complex binds to and activates the myosin light chain kinase (MLCK), which in turn phosphorylates MLC20. When MLC20 remains phosphorylated all along the crossbridge cycle, crossbridge cycling is fast. However, sustained contraction can occur even if $\left[\mathrm{Ca}^{2+}\right]$ i and subsequent MLC20 phosphorylation decrease [62], due to the fact that if dephosphorylation of MLC20 occurs after the attachment of myosin on actin, crossbridge cycle goes on but at a slower rate, in particular in the stage where dephosphorylated myosin detaches actin. These maintained dephosphorylated crossbridges that cycle at a slow rate are called latch-bridges. The contractile apparatus can hence be represented as a 4 -state system $[63,64]$.

\section{Modulation of the sensitivity of the contractile apparatus to $\mathrm{Ca}^{2+}$}

Both MLCK and MLCP activity can be modulated by several protein kinases such as protein kinase A (PKA), protein kinase C (PKC) and Rho kinase (RhoK), which hence indirectly modulate the activity of the contractile apparatus [57,59,62,65-67]. Additionally, actin-myosin interaction can be modulated by proteins associated to the thin filament of actin such as caldesmon and calponin, which modulation depends on their phosphorylation by several protein kinases. It appears then that in ASM, the canonical $\mathrm{Ca}^{2+}$-activated MLCK/MLCP enzymatic balance is embedded in a complex network of signalling pathways that can alter, for a given $\mathrm{Ca}^{2+}$ signal, the subsequent contractile response, namely, capable of modulating the sensitivity of the contractile apparatus to $\mathrm{Ca}^{2+}[59]$.

Relaxant agonists: Relaxant agonists, namely, agonists able to inhibit the contractile response to contracting agonists, can act either upstream the $\mathrm{Ca}^{2+}$ signal, by decreasing the $\mathrm{Ca}^{2+}$ response to the stimulation, or downstream, by decreasing the sensitivity to $\mathrm{Ca}^{2+}$ of the contractile apparatus. For example, $\beta 2$-agonists acts on $\beta 2$-adrenergic receptors that are coupled to Gs protein associated with adenylcyclase (AC) [66]. This enzyme catalyses the formation of cyclic AMP (cAMP) from ATP. cAMP activates a cAMP-dependent protein kinase (PKA), which induces relaxation by two main additive mechanisms. On the one hand, PKA inhibits PLC and hence InsP3-induced $\mathrm{Ca}^{2+}$ release, and, on the other hand, it inhibits MLCK and hence MLC20 phosphorylation and contraction independently from Ca2+ [68]. Additionally, cAMPmediated agonists have been shown to induce relaxation by decreasing the $\mathrm{Ca}^{2+}$ signal, via reduction of the sensitivity of InsP3R [69].

\section{Hyperreactivity}

Bronchial hyperesponsiveness (BHR), or hyperexcitability, is a functional anomaly characterized by an acute, excessive or disproportionate bronchial obstruction, in response to various stimuli. BHR is a critical but nonspecific component of asthma, found also in chronic obstructive pulmonary diseases (COPD). The mechanisms responsible for BHR are still partially unknown. ASM is one of the main effectors of BHR. The efficiency of pharmacological relaxants acting on ASMCs, like $\beta 2$-mimetics, in the treatment of the bronchial obstruction is an evidence of its implication. Structural changes of ASM have been highlighted, associated with an increase in the contractile properties. The other components of the bronchial wall and the pulmonary parenchyma, namely epithelium, structure of the cartilage, elasticity of the pulmonary parenchyma, inflammatory infiltration, bronchial secretions, and vessels, can contribute either to modify the contractility of the muscle itself, or to modify the load against which it contracts, or finally to inhibit the bronchial obstruction directly [70-73]. Among the hypotheses about the mechanisms of BHR, modifications of the contractile mechanisms of the smooth muscle were particularly studied. The mechanical response of the smooth muscle is modified during the initial phase of the contraction: increase in the amplitude and the speed of muscle shortening, decrease in internal resistance to shortening, and increase in half-relaxation time. Alterations of calcium homeostasis in ASMCs induced by inflammatory mediators and cytokines, seem to be the base of non-specific BHR [74]. In addition to alteration of the contractile properties of the ASMC, hyperreactivity may be due to overstimulation of ASMCs by contracting agonists.

\section{Conclusion}

In conclusion, it appears that ASMC, by determining the lumen of the airway and hence air flow rate, is a key element of lung physiology. ASMC contractile state is under control of several extracellular agonists acting on plasma membrane receptors. The shape of the resulting calcium signal is sensed by the contractile apparatus and hence determines the pattern of the contractile response. Agonists can also modify the sensitivity of the contractile apparatus to calcium, via phosphorylation and dephosphorylation of a network of regulatory proteins. These mechanisms can be altered in several respiratory diseases such and COPD, asthma, or exposure to air pollutants, leading to hyperreactivity, which can be pharmacologically controlled by drugs acting on the mechanisms of ASM contraction. 


\section{References}

1. Otis $A B$ (1983) A perspective of respiratory mechanics. J Appl Physiol Respir Environ Exerc Physiol 54: 1183-1187.

2. Berair R, Hollins F, Brightling C (2013) Airway smooth muscle hypercontractility in asthma. J Allergy (Cairo) 2013: 185971.

3. Bossé Y, Rousseau E, Amrani Y, Grunstein MM (2013) Smooth muscle hypercontractility in airway hyperresponsiveness: innate, acquired, or nonexistent? J Allergy (Cairo) 2013: 938046

4. Pascoe CD, Wang L, Syyong HT, Paré PD (2012) A Brief History of Airway Smooth Muscle's Role in Airway Hyperresponsiveness. J Allergy (Cairo) 2012 768982

5. West AR, Syyong HT, Siddiqui S, Pascoe CD, Murphy TM, et al. (2013) Airway contractility and remodeling: links to asthma symptoms. Pulm Pharmacol Ther 26: $3-12$

6. Roux E, Duvert M, Marthan R (2002) Combined effect of chronic hypoxia and in vitro exposure to gas pollutants on airway reactivity. Am J Physiol Lung Cell Mol Physiol 283: L628-635

7. Roux E, Guibert C, Crevel H, Savineau JP, Marthan R (1996) Human and rat airway smooth muscle responsiveness after ozone exposure in vitro. Am J Physiol 271: L631-636.

8. Fowkes FG, Lunn JN, Farrow SC, Robertson IB, Samuel P (1982) Epidemiology in anaesthesia. III: Mortality risk in patients with coexisting physical disease. $\mathrm{Br}$ J Anaesth 54: 819-825.

9. Hirshman CA, Edelstein G, Peetz S, Wayne R, Downes H (1982) Mechanism of action of inhalational anesthesia on airways. Anesthesiology 56: 107-111.

10. Roux E (2013) Temporal aspects of calcium signaling in airways smooth muscle cells. In Calcium Signaling In Airway Smooth Muscle Cells. Edited by Wang YX. New York: Springer.

11. Barnes PJ (1992) Modulation of neurotransmission in airways. Physiol Rev 72 699-729.

12. WIDDICOMBE JG (1963) Regulation of tracheobronchial smooth muscle. Physiol Rev 43: 1-37.

13. Daniel EE, Kannan M, Davis C, Posey-Daniel V (1986) Ultrastructural studies on the neuromuscular control of human tracheal and bronchial muscle. Respir Physiol 63: 109-128.

14. Canning BJ, Undem BJ (1994) Parasympathetic innervation of airways smooth muscle. In Airways smooth muscle: structure, innervation and neurotransmission. Edited by Raeburn D, Giembycz M. Basel: Birkhäuser Verlag.

15. Coburn RF (1987) Peripheral airway ganglia. Annu Rev Physiol 49: 573-582.

16. Roux E, Molimard M, Savineau JP, Marthan R (1998) Muscarinic stimulation of airway smooth muscle cells. Gen Pharmacol 31: 349-356.

17. Ind PW (1994) Role of the sympathetic nervous system and endogenous catecholamines in the regulation of airways smooth muscle tone. In Airways smooth muscle: structure, innervation and neurotransmission. Edited by Raeburn D, Giembycz M. Basel: Birkhäuser Verlag

18. Pack RJ, Richardson PS (1984) The aminergic innervation of the human bronchus: a light and electron microscopic study. J Anat 138: 493-502.

19. Rhoden KJ, Meldrum LA, Barnes PJ (1988) Inhibition of cholinergic neurotransmission in human airways by beta 2-adrenoceptors. J Appl Physio (1985) 65: 700-705.

20. Burnstock G (2013) Purinergic signalling: pathophysiology and therapeutic potential. Keio J Med 62: 63-73

21. Jartti T (2001) Asthma, asthma medication and autonomic nervous system dysfunction. Clin Physiol 21: 260-269.

22. Chand N, Duane Sofia R (1995) Histamine. In Airways smooth muscle: neurotransmitters, amines, lipid mediators and signal transduction. Edited by Raeburn D, Giembycz MA. Basel: Birkhäuser Verlag.

23. FitzPatrick M, Donovan C, Bourke JE (2014) Prostaglandin E2 elicits greate bronchodilation than salbutamol in mouse intrapulmonary airways in lung slices. Pulm Pharmacol Ther 28: 68-76.

24. Hay DWP (1994) Endothelins. In Airways smooth muscle: peptide receptors, ion channels and signal transduction. Edited by Raeburn D, Giembycz MA Basel: Birkhäuser Verlag.
25. Hay DWP, Raeburn D (1995) Leukotrienes, In Airways smooth muscle: neurotransmitters, amines, lipid mediators and signal transduction. Edited by Raeburn D, Giembycz MA. Basel: Birkhäuser Verlag

26. Hyvelin JM, Roux E, Prévost MC, Savineau JP, Marthan R (2000) Cellular mechanisms of acrolein-induced alteration in calcium signaling in airway smooth muscle. Toxicol Appl Pharmacol 164: 176-183.

27. Marthan R, Martin C, Amédée T, Mironneau J (1989) Calcium channel currents in isolated smooth muscle cells from human bronchus. J Appl Physiol (1985) 66: 1706-1714.

28. Kirkpatrick CT (1981) Tracheobronchial smooth muscle. In Smooth muscle: an assessment of current knowledge. Edited by Bülbring $E$, Brading A, Jones A Tomida T. London: Edward Arnold.

29. Xiao JH, Wang YX, Zheng YM (2013) Transient Receptor Potential and Ora channels in airway smooth muscle cells. In Calcium Signaling In Airway Smooth Muscle Cells. Edited by Wang YX. New York: Springer.

30. Roux E, Noble PJ, Noble D, Marhl M (2006) Modelling of calcium handling in airway myocytes. Prog Biophys Mol Biol 90: 64-87.

31. Mounkaïla B, Marthan R, Roux E (2005) Biphasic effect of extracellular ATP on human and rat airways is due to multiple $\mathrm{P} 2$ purinoceptor activation. Respir Res 6: 143.

32. Flores-Soto E, Carbajal V, Reyes-García J, García-Hernández LM, Figueroa A, et al. (2011) In airways ATP refills sarcoplasmic reticulum via P2X smooth muscle receptors and induces contraction through $\mathrm{P} 2 \mathrm{Y}$ epithelial receptors. Pflugers Arch 461: 261-275.

33. Liao Y, Erxleben C, Abramowitz J, Flockerzi V, Zhu MX, et al. (2008) Functiona interactions among Orai1, TRPCs, and STIM1 suggest a STIM-regulated heteromeric Orai/TRPC model for SOCE/lcrac channels. Proc Natl Acad Sci U S A 105: 2895-2900.

34. Salido GM, Jardín I, Rosado JA (2011) The TRPC ion channels: association with Orai1 and STIM1 proteins and participation in capacitative and noncapacitative calcium entry. Adv Exp Med Biol 704: 413-433.

35. Peel SE, Liu B, Hall IP (2006) A key role for STIM1 in store operated calcium channel activation in airway smooth muscle. Respir Res 7: 119.

36. Peel SE, Liu B, Hall IP (2008) ORAI and store-operated calcium influx in human airway smooth muscle cells. Am J Respir Cell Mol Biol 38: 744-749.

37. Prakash YS, Pabelick CM, Kannan MS, Sieck GC (2000) Spatial and tempora aspects of ACh-induced [ $\left.\mathrm{Ca}^{2+}\right]$ i oscillations in porcine tracheal smooth muscle. Cell Calcium 27: 153-162.

38. Perusquía M, Flores-Soto E, Sommer B, Campuzano-González E, MartínezVilla I, et al. (2014) Testosterone-induced relaxation involves L-type and storeoperated $\mathrm{Ca}^{2+}$ channels blockade, and PGE 2 in guinea pig airway smooth muscle. Pflugers Arch.

39. Gao YD, Zheng JW, Li P, Cheng M, Yang J (2013) Store-operated $\mathrm{Ca}^{2+}$ entry is involved in transforming growth factor- $-^{2} 1$ facilitated proliferation of rat airway smooth muscle cells. J Asthma 50: 439-448.

40. Zou JJ, Gao YD, Geng S, Yang J (2011) Role of STIM1/Orai1-mediated storeoperated $\mathrm{Ca}^{2+}$ entry in airway smooth muscle cell proliferation. J Appl Physio (1985) 110: 1256-1263.

41. Flores-Soto E, Reyes-García J, Sommer B, Montaño LM (2013) Sarcoplasmic reticulum $\mathrm{Ca}(2+)$ refilling is determined by $L$-type $\mathrm{Ca}(2+)$ and store operated $\mathrm{Ca}(2+)$ channels in guinea pig airway smooth muscle. Eur $\mathrm{J}$ Pharmacol 721 $21-28$

42. Bai $Y$, Edelmann M, Sanderson MJ (2009) The contribution of inosito 1,4,5-trisphosphate and ryanodine receptors to agonist-induced $\mathrm{Ca}(2+)$ signaling of airway smooth muscle cells. Am J Physiol Lung Cell Mol Physio 297: L347-361.

43. Deepak A, Deshpande DA, Guedes A, Dileepan M, Walseth TF, et al. (2013) CD38-clycli ADP-ribose-mediated calcium signaling in airway myocytes. In Calcium Signaling In Airway Smooth Muscle Cells. Edited by Wang YX. New York: Springer.

44. Prakash YS, Kannan MS, Walseth TF, Sieck GC (1998) Role of cyclic ADPribose in the regulation of $\left[\mathrm{Ca}^{2+}\right] \mathrm{i}$ in porcine tracheal smooth muscle. Am J Physiol 274: C1653-1660.

45. Kannan MS, Prakash YS, Brenner T, Mickelson JR, Sieck GC (1997) Role of ryanodine receptor channels in $\mathrm{Ca}^{2+}$ oscillations of porcine tracheal smooth muscle. Am J Physiol 272: L659-664. 
46. Prakash YS, Kannan MS, Sieck GC (1997) Regulation of intracellular calcium oscillations in porcine tracheal smooth muscle cells. Am J Physiol 272: C966975

47. Bai Y, Sanderson MJ (2009) The contribution of $\mathrm{Ca}^{2+}$ signaling and $\mathrm{Ca}^{2+}$ sensitivity to the regulation of airway smooth muscle contraction is different in rats and mice. Am J Physiol Lung Cell Mol Physiol 296: L947-958.

48. Hyvelin JM, Martin C, Roux E, Marthan R, Savineau JP (2000) Human isolated bronchial smooth muscle contains functional ryanodine/caffeine-sensitive Carelease channels. Am J Respir Crit Care Med 162: 687-694.

49. Mei L, Zheng YM, Wang YX (2013) Ryanodine and inositol trsiphosphate receptors $/ \mathrm{Ca}^{2+}$ release channels in airway smooth muscle cells. In Calcium Signaling In Airway Smooth Muscle Cells. Edited by Wang YX. New York: Springer.

50. Sanders KM (2001) Invited review: mechanisms of calcium handling in smooth muscles. J Appl Physiol (1985) 91: 1438-1449.

51. Roux E, Marhl M (2004) Role of sarcoplasmic reticulum and mitochondria in $\mathrm{Ca}^{2+}$ removal in airway myocytes. Biophys J 86: 2583-2595.

52. Roux E, Mazat J-P, Marhl M (2009) Role of mitochondria in calcium homeostasis and contraction of smooth muscle cells. In Mitochondria: Structure, Functions and Dysfunctions. Edited by Svensson OL. Hauppauge NY: Nova Publisher.

53. Marhl M, Gosak M, Perc M, Roux E (2010) Importance of cell variability for calcium signaling in rat airway myocytes. Biophys Chem 148: 42-50.

54. Gunter TE, Buntinas L, Sparagna G, Eliseev R, Gunter K (2000) Mitochondrial calcium transport: mechanisms and functions. Cell Calcium 28: 285-296.

55. Perez JF, Sanderson MJ (2005) The frequency of calcium oscillations induced by $5-\mathrm{HT}, \mathrm{ACH}$, and $\mathrm{KCl}$ determine the contraction of smooth muscle cells of intrapulmonary bronchioles. J Gen Physiol 125: 535-553.

56. Roux E, Guibert C, Savineau JP, Marthan R (1997) [Ca ${ }^{2+}$ i oscillations induced by muscarinic stimulation in airway smooth muscle cells: receptor subtypes and correlation with the mechanical activity. Br J Pharmacol 120: 1294-1301.

57. Mbikou P, Fajmut A, Brumen M, Roux E (2011) Contribution of Rho kinase to the early phase of the calcium-contraction coupling in airway smooth muscle. Exp Physiol 96: 240-258.

58. Mbikou P, Roux E, Fajmut A (2010) Couplage excitation-contraction du muscle lisse des voies aeriennes. Sarrebruck: Éditions universitaires européennes.

59. Roux E, Mbikou P, Fajmut A (2012) Role of Protein Kinase Network in ExcitationContraction Coupling in Smooth Muscle Cell. In Protein Kinases. Edited by Da Silva Xavier G. Rijeka: InTech : 287-320.

60. Kuo KH, Herrera AM, Seow CY (2003) Ultrastructure of airway smooth muscle. Respir Physiol Neurobiol 137: 197-208.
61. Somlyo AP, Somlyo AV, Kitazawa T, Bond M, Shuman H, et al. (1983) Ultrastructure, function and composition of smooth muscle. Ann Biomed Eng 11: $579-588$

62. Mbikou P, Fajmut A, Brumen M, Roux E (2006) Theoretical and experimental investigation of calcium-contraction coupling in airway smooth muscle. Cell Biochem Biophys 46: 233-252.

63. Hai CM, Murphy RA (1988) Regulation of shortening velocity by cross-bridge phosphorylation in smooth muscle. Am J Physiol 255: C86-94.

64. Hai CM, Murphy RA (1988) Cross-bridge phosphorylation and regulation of latch state in smooth muscle. Am J Physiol 254: C99-106.

65. Billington CK, Ojo OO, Penn RB, Ito S (2013) cAMP regulation of airway smooth muscle function. Pulm Pharmacol Ther 26: 112-120.

66. Morgan SJ, Deshpande DA, Tiegs BC, Misior AM, Yan H, et al. (2014) $\hat{I}^{2}$-Agonistmediated relaxation of airway smooth muscle is protein kinase A-dependent. $J$ Biol Chem 289: 23065-23074.

67. Mukherjee S, Trice J, Shinde P, Willis RE, Pressley TA, et al. (2013) $\mathrm{Ca}^{2+}$ oscillations, $\mathrm{Ca}^{2+}$ sensitization, and contraction activated by protein kinase $\mathrm{C}$ in small airway smooth muscle. J Gen Physiol 141: 165-178.

68. Hakonarson H, Grunstein MM (1998) Regulation of second messengers associated with airway smooth muscle contraction and relaxation. Am J Respir Crit Care Med 158: S115-122.

69. Bai Y, Sanderson MJ (2006) Airway smooth muscle relaxation results from a reduction in the frequency of $\mathrm{Ca}^{2+}$ oscillations induced by a cAMP-mediated inhibition of the IP3 receptor. Respir Res 7: 34 .

70. Brusasco V, Pellegrino R (2003) Complexity of factors modulating airway narrowing in vivo: relevance to assessment of airway hyperresponsiveness. $J$ Appl Physiol (1985) 95: 1305-1313.

71. Duguet A, Biyah K, Minshall E, Gomes R, Wang CG, et al. (2000) Bronchia responsiveness among inbred mouse strains. Role of airway smooth-muscle shortening velocity. Am J Respir Crit Care Med 161: 839-848.

72. Folkerts G, Nijkamp FP (1998) Airway epithelium: more than just a barrier! Trends Pharmacol Sci 19: 334-341.

73. Marthan R, Stephens NL (1994) [Mechanisms of bronchial hyperreactivity. Role of smooth muscle]. Rev Mal Respir 11: 149-159.

74. Amrani Y, Tliba O, Deshpande DA, Walseth TF, Kannan MS, et al. (2004) Bronchial hyperresponsiveness: insights into new signaling molecules. Curr Opin Pharmacol 4: 230-234. 